\title{
Effects of feeding wheat or corn-wheat dried distillers grains with solubles in low- or high-crude protein diets on ruminal function, omasal nutrient flows, urea- $\mathrm{N}$ recycling, and performance in cows
}

\author{
G. E. Chibisa and T. Mutsvangwa ${ }^{1}$ \\ Department of Animal and Poultry Science, University of Saskatchewan, Saskatoon, SK, Canada, S7N 5A8
}

\begin{abstract}
A study was conducted to determine the effects of including either wheat-based (W-DDGS) or corn-wheat blend (B-DDGS) dried distillers grains with solubles as the major protein source in low- or high-crude protein (CP) diets fed to dairy cows on ruminal function, microbial protein synthesis, omasal nutrient flows, urea-N recycling, and milk production. Eight lactating Holstein cows $(768.5 \pm 57.7 \mathrm{~kg}$ of body weight; $109.5 \pm 40.0 \mathrm{~d}$ in milk) were used in a replicated $4 \times 4$ Latin square design with 28 - $\mathrm{d}$ periods (18 d of dietary adaptation and $10 \mathrm{~d}$ of measurements) and a $2 \times 2$ factorial arrangement of dietary treatments. Four cows in one Latin square were ruminally cannulated for the measurement of ruminal fermentation characteristics, microbial protein synthesis, urea-N recycling kinetics, and omasal nutrient flow. The treatment factors were type of distillers co-product (W-DDGS vs. B-DDGS) and dietary CP content [15.2 vs. $17.3 \%$; dry matter (DM) basis]. The B-DDGS was produced from a mixture of $15 \%$ wheat and $85 \%$ corn grain. All diets were formulated to contain $10 \%$ W-DDGS or B-DDGS on a DM basis. No diet effect was observed on DM intake. Yields of milk, fat, protein, and lactose, and plasma urea-N and milk urea-N concentrations were lower in cows fed the low-CP compared with those fed the high-CP diet. Although feeding B-DDGS tended to reduce ruminal ammonia- $\mathrm{N}\left(\mathrm{NH}_{3}-\mathrm{N}\right)$ concentration compared with feeding W-DDGS (9.3 vs. 10.5 $\mathrm{mg} / \mathrm{dL}$ ), no differences were observed in plasma urea-N and milk urea- $\mathrm{N}$ concentrations. Additionally, dietary inclusion of B-DDGS compared with W-DDGS did not affect rumen-degradable protein supply, omasal flows of total N, microbial nonammonia N (NAN), rumen-undegradable protein, and total NAN, or urea-N recycling kinetics and milk production. However, cows fed the low-CP diet had lower $\mathrm{N}$ intake, rumen-degradable protein supply, ruminal $\mathrm{NH}_{3}-\mathrm{N}$ concentration, and omasal
\end{abstract}

Received January 25, 2013.

Accepted June 22, 2013.

${ }^{1}$ Corresponding author: tim.mutsvan@usask.ca flows of N, microbial NAN, and total NAN compared with those fed the high-CP diet. Feeding the low-CP compared with the high-CP diet also resulted in lower endogenous urea- $\mathrm{N}$ production, urea- $\mathrm{N}$ recycled to the gastrointestinal tract, and urea- $\mathrm{N}$ excretion in urine. In summary, our results indicate that both W-DDGS and B-DDGS can be included as the major protein sources in dairy cow diets without compromising nutrient supply and production performance. However, feeding the low-CP diet lowered omasal flows of microbial protein and metabolizable protein, which, in turn, resulted in lower milk production compared with feeding the highCP diet.

Key words: dairy cow, dried distillers grains with solubles, microbial protein, omasal nutrient flow

\section{INTRODUCTION}

Historically, wheat has been the major feedstock used for ethanol production in western Canada. However, fluctuations in the price of wheat in recent years have resulted in corn being increasingly used in combination with wheat in different ratios based on least cost and availability (Nuez-Ortín and Yu, 2011; Abdelqader and Oba, 2012). Therefore, both wheatbased (W-DDGS) and corn-wheat blend (B-DDGS) dried distillers grains with solubles are available for use in dairy cow diets. Wheat DDGS can be used to either partially or completely replace barley forage and grain (Zhang et al., 2010a,b) or canola meal (Chibisa et al., 2012) in lactating cow diets without negatively affecting animal performance. However, compared with W-DDGS, limited information exists on the feeding value of B-DDGS. As the proportion of corn to wheat increases in the feedstock, the $\mathrm{CP}$ content and ruminal CP degradability of B-DDGS decrease compared with W-DDGS (Boila and Ingalls, 1994a,b; Nuez Ortín and $\mathrm{Yu}, 2009)$. Therefore, compared with W-DDGS, the inclusion of B-DDGS in dairy cow diets could potentially reduce dietary RDP supply, thus causing a deficiency in ruminal $\mathrm{NH}_{3}-\mathrm{N}$, which could suppress microbial protein synthesis in the rumen. In vitro estimates of microbial protein synthesis were lower for B-DDGS 
compared with W-DDGS (138.8 vs. $160.6 \mathrm{~g} / \mathrm{kg}$ of DM; Nuez-Ortín and Yu, 2010). Abdelqader and Oba (2012) reported a lower ruminal $\mathrm{NH}_{3}-\mathrm{N}$ concentration when isonitrogenous diets fed to cows contained B-DDGS (a mixture of $50 \%$ corn-based DDGS and 50\% W-DDGS) compared with $100 \%$ W-DDGS, but dietary effects on RDP supply, ruminal microbial protein production, and postruminal flow of MP were not measured. Dietary $\mathrm{CP}$ content can also have major effects on RDP supply, as the amount of dietary $\mathrm{CP}$ that is degraded in the rumen increases with dietary $\mathrm{CP}$ content (Olmos Colmenero and Broderick, 2006b). When dietary CP content is reduced in diets containing either W-DDGS or B-DDGS as the major protein sources (which could potentially alter RDP supply), it is important to determine how changing dietary $\mathrm{CP}$ content and RDP supply interact to alter $\mathrm{N}$ utilization and production responses.

Urea-N recycling buffers the rumen from low $\mathrm{NH}_{3^{-}}$ $\mathrm{N}$ concentrations and, thus, can maintain microbial growth when dietary RDP supply is limited (Huhtanen and Hristov, 2009; Agle et al.; 2010). It is known that a greater proportion of endogenous urea- $\mathrm{N}$ is recycled to the rumen when dietary CP content is reduced (Lapierre and Lobley, 2001). Under such feeding conditions, the fractional contribution of $\mathrm{NH}_{3}-\mathrm{N}$ from recycled urea- $\mathrm{N}$ to microbial protein synthesis increases (Marini and Van Amburgh, 2003). Therefore, the potential decrease in ruminal $\mathrm{NH}_{3}-\mathrm{N}$ concentration when feeding B-DDGS compared with W-DDGS could increase the rate of urea-N transfer into the rumen and its subsequent sequestration into microbial protein. When corn-based DDGS (a low-RDP source) was compared with urea (a high-RDP source) as a $\mathrm{N}$ supplement in steers fed corn-based diets, both urea- $\mathrm{N}$ recycling to the gastrointestinal tract (GIT) and the proportion of microbial NAN arriving at the small intestine that was derived from recycled urea- $\mathrm{N}$ tended to be greater with corn-based DDGS (Brake et al., 2010). This suggests that recycled urea-N might be a more important source of $\mathrm{N}$ for ruminal microbial growth when high-RUP supplemental protein sources such as B-DDGS are fed (Wickersham et al., 2009b; Brake et al., 2010).

The objective of this study was to determine how interactions between the type of distillers co-product (W-DDGS vs. B-DDGS) and diet CP content (15 vs. $17 \%$ ) alter ruminal $\mathrm{N}$ utilization, urea-N recycling to the GIT, omasal nutrient flow, and production performance in lactating dairy cows. We hypothesized that at similar dietary $\mathrm{CP}$ content, differences in the RDP content between W-DDGS and B-DDGS would result in differences in ruminal $\mathrm{N}$ utilization, urea- $\mathrm{N}$ recycling to the GIT, and omasal nutrient flow.

\section{MATERIALS AND METHODS}

\section{Animals and Experimental Design}

Eight lactating dairy cows $(768.5 \pm 57.7 \mathrm{~kg}$ of BW; $109.5 \pm 40.0$ DIM) were used in a replicated $4 \times 4$ Latin square design with 28 -d periods (20 d of dietary adaptation and $8 \mathrm{~d}$ of measurements) and a $2 \times 2$ factorial arrangement of dietary treatments. Four cows in 1 Latin square were ruminally cannulated for the measurement of ruminal fermentation characteristics, microbial protein synthesis, urea-N recycling kinetics, and omasal nutrient flows. All cows were housed in individual tie-stalls at the Greenbrae Dairy Research Facility (University of Saskatchewan, Saskatoon, SK, Canada). The University of Saskatchewan Animal Care Committee approved the use of cows for this experiment (UCACS Protocol No. 20040048), and they were cared for in accordance with the Canadian Council on Animal Care (1993) regulations.

\section{Experimental Treatments and Feeding Management}

The treatment factors were type of distillers co-product (W-DDGS vs. B-DDGS) and dietary CP content (15 vs. $17 \%$, DM basis). In a previous study (Broderick, 2003), feeding diets containing 15.1, 16.7, and $18.4 \%$ $\mathrm{CP}$ resulted in a linear increase in DMI, but milk yield increased only when feeding diets containing between 15.1 and $16.7 \%$ CP. For the current study, therefore, we decided to use dietary CP contents of 15 and $17 \%$ to encompass the range in which positive responses in milk yield have been observed. All diets were formulated to contain $10 \%$ (on a DM basis) W-DDGS or B-DDGS. Single batches of W-DDGS and B-DDGS were used for the entire study. The batch of W-DDGS was produced from $100 \%$ wheat (Terra Grain Fuels, Belle Plaine, SK, Canada), whereas the batch of B-DDGS was produced from $85 \%$ corn and 15\% wheat (Husky Energy Inc., Minnedosa, MB, Canada). Cows were fed twice daily at 0900 and $1600 \mathrm{~h}$ as TMR for ad libitum intake. The forage:concentrate ratio of the TMR was 50:50, with the forage component of the TMR being a mixture of barley silage ( $65 \%$ on a DM basis) and chopped alfalfa hay $(35 \%$; Table 1$)$.

\section{Data Collection and Sampling}

Urea-N recycling kinetics, $\mathrm{N}$ balance, apparent total-tract nutrient digestion, ruminal fermentation characteristics, microbial protein synthesis, and omasal nutrient flow were determined using the 4 ruminally cannulated cows in 1 Latin square. On d 21 (0900 h) of each experimental period, the 4 ruminally cannulated 
Table 1. Ingredient and chemical composition of diets containing low- or high-CP contents, with either wheatbased dried distillers grains with solubles (W-DDGS) or wheat-corn blend DDGS (B-DDGS) as the major protein source

\begin{tabular}{|c|c|c|c|c|}
\hline \multirow[b]{2}{*}{ Item } & \multicolumn{2}{|c|}{ Low-CP diet } & \multicolumn{2}{|c|}{ High-CP diet } \\
\hline & W-DDGS & B-DDGS & W-DDGS & B-DDGS \\
\hline \multicolumn{5}{|c|}{ Ingredient composition ( $\%$ of diet DM) } \\
\hline Alfalfa hay & 17.8 & 17.8 & 17.8 & 17.8 \\
\hline Barley silage & 31.2 & 31.2 & 31.2 & 31.2 \\
\hline Soybean hulls & 2.2 & 2.7 & 0.45 & 0.22 \\
\hline Cottonseed hulls & 3.6 & 2.2 & 0.45 & 0.22 \\
\hline Barley grain & 29.0 & 29.0 & 29.0 & 29.0 \\
\hline W-DDGS & 10.0 & - & 10.0 & - \\
\hline B-DDGS & - & 10.0 & - & 10.0 \\
\hline Canola meal & 0.89 & 1.1 & 3.3 & 2.2 \\
\hline Corn gluten meal & 0.45 & 1.1 & 1.1 & 2.7 \\
\hline Soybean meal & 0.45 & 0.45 & 2.2 & 2.2 \\
\hline Fat canola oil & 0.60 & 0.60 & 0.60 & 0.60 \\
\hline Molasses & 0.24 & 0.24 & 0.24 & 0.24 \\
\hline Mineral-vitamin $\operatorname{mix}^{1}$ & 1.8 & 1.8 & 1.8 & 1.8 \\
\hline Sodium bicarbonate & 0.97 & 0.97 & 0.97 & 0.97 \\
\hline Salt & 0.36 & 0.36 & 0.36 & 0.36 \\
\hline Limestone & 0.24 & 0.24 & 0.24 & 0.24 \\
\hline Dynamate $^{2}$ & 0.17 & 0.17 & 0.17 & 0.17 \\
\hline \multicolumn{5}{|l|}{ Chemical composition } \\
\hline DM $(\%)$ & 54.6 & 54.4 & 54.9 & 54.5 \\
\hline $\mathrm{OM}(\%$ of $\mathrm{DM})$ & 94.0 & 94.1 & 93.9 & 94.1 \\
\hline $\mathrm{CP}(\%$ of $\mathrm{DM})$ & 15.0 & 15.3 & 17.2 & 17.4 \\
\hline Fat $(\%$ of $\mathrm{DM})$ & 3.67 & 4.65 & 4.23 & 4.83 \\
\hline $\mathrm{NDF}(\%$ of $\mathrm{DM})$ & 35.2 & 34.9 & 32.6 & 32.5 \\
\hline $\mathrm{ADF}(\%$ of $\mathrm{DM})$ & 19.2 & 18.7 & 17.6 & 17.0 \\
\hline $\mathrm{NE}_{\mathrm{L}}^{3}(\mathrm{Mcal} / \mathrm{kg})$ & 1.68 & 1.70 & 1.74 & 1.75 \\
\hline
\end{tabular}

${ }^{1}$ Contained (/kg of premix; DM basis) 330,000 IU of vitamin A, 60,000 IU of vitamin D, 1,000 IU of vitamin E, $16 \%, \mathrm{Ca}, 8.5 \% \mathrm{P}, 6.3 \% \mathrm{Na}, 4.5 \% \mathrm{Mg}, 2,100 \mathrm{mg}$ of $\mathrm{Zn}, 1,500 \mathrm{mg}$ of $\mathrm{Mn}, 535 \mathrm{mg}$ of Cu, $12 \mathrm{mg}$ of Se, and 45 mg of I.

${ }^{2}$ Dynamate (Eastern Minerals Inc., Henderson, NC) contained $18 \% \mathrm{~K}, 11 \% \mathrm{Mg}$, and $22 \% \mathrm{~S}$.

${ }^{3}$ Estimated using CPM Dairy software (v 3.0.8; Cornell University, Ithaca, NY; University of Pennsylvania, Kennett Square, PA; and William H. Miner Agricultural Research Institute, Chazy, NY) using the chemical analysis of feed ingredients.

cows were fitted with temporary vinyl catheters $(0.86$ mm i.d. $\times 1.32-m m$ o.d.; Scientific Commodities Inc., Lake Havasu City, AZ) in the right and left jugular veins to facilitate continuous isotope infusion and blood sampling. Urea-N transfer to the GIT and whole-body $\mathrm{N}$ balance were subsequently determined from d 22 to 26, as described by Lobley et al. (2000). Briefly, urine and fecal samples were collected on d 21 for analysis of ${ }^{15} \mathrm{~N}$ natural abundance. Thereafter, continuous infusion of double-labeled urea $\left(\left[{ }^{15} \mathrm{~N}^{15} \mathrm{~N}\right]\right.$-urea, 99.8 atom $\%{ }^{15} \mathrm{~N}$; Cambridge Isotope Laboratories Inc., Andover, MA) prepared in $0.15 \mathrm{M}$ sterile saline started at $0800 \mathrm{~h}$ on d 22 of each experimental period and ended at $0600 \mathrm{~h}$ on d 28. Individual cow $\mathrm{N}$ intake from d 13 to 20 was used to determine the daily $\left[{ }^{15} \mathrm{~N}^{15} \mathrm{~N}\right]$-urea dosage rate, based on a targeted plateau urinary $\left[{ }^{15} \mathrm{~N}^{15} \mathrm{~N}\right]$-urea enrichment of 0.15 atom percent excess (APE). Total fecal and urine collections were conducted from $0800 \mathrm{~h}$ on d 22 to $0800 \mathrm{~h}$ on d $26(96 \mathrm{~h})$. Large steel trays placed behind each stall were used to collect feces. On each day, fecal output for each cow was thoroughly mixed and quantitatively transferred to preweighed plastic tubs for weighing. Subsequently, a $2.5 \%$ fecal subsample was collected and stored at $-20^{\circ} \mathrm{C}$ for later chemical analysis. Indwelling Bardex Foley bladder catheters (26 Fr, 75 cc ribbed balloon, lubricious-coated; C. R. Bard Inc., Covington, GA) used for total urine collection were inserted at $0800 \mathrm{~h}$ on $\mathrm{d} 21$ before connection to urine collection tubing at the start of $\left[{ }^{15} \mathrm{~N}^{15} \mathrm{~N}\right]$-urea infusion $(0800 \mathrm{~h}$ on $\mathrm{d} 22)$. Urine was collected into 20-L carboy polyethylene containers containing $150 \mathrm{~mL}$ of concentrated $\mathrm{HCl}$, and this acidification $(\mathrm{pH}<3)$ of urine during collection was necessary to prevent microbial growth and volatilization of $\mathrm{NH}_{3}-\mathrm{N}$. Daily urine output was recorded, before collection of a $5 \%$ subsample that was pooled by cow for each period and stored at $-20^{\circ} \mathrm{C}$ for later $\mathrm{N}$ analysis. A daily $50-\mathrm{mL}$ urine sample was also collected (d 23 to 26) and stored at $-20^{\circ} \mathrm{C}$ for later analysis of urinary enrichments of $\left[{ }^{15} \mathrm{~N}^{15} \mathrm{~N}\right]$ - and $\left[{ }^{14} \mathrm{~N}^{15} \mathrm{~N}\right]$-urea. Additionally, a 2-mL urine 
sample was diluted with $8 \mathrm{~mL}$ of distilled water and stored at $-20^{\circ} \mathrm{C}$ until analysis for urea-N.

To measure the flow of nutrients at the omasal canal, $\mathrm{YbCl}_{3}$ (Siddons et al., 1985; Yang and Beauchemin, 2005) was used as a digesta marker. On d 21 of each experimental period, a $500-\mathrm{mL}$ omasal digesta sample was collected for determination of background ${ }^{15} \mathrm{~N}$ $\left({ }^{15} \mathrm{NB}\right)$ abundance. A priming dose of $\mathrm{YbCl}_{3}$ that was equivalent to half the daily dose was then administered into the rumen via the ruminal cannula. Subsequently, a $\mathrm{YbCl}_{3}$ solution was continuously infused into the rumen using a peristaltic pump (model 205U; WatsonMarlow Pumps Group, Cornwall, UK) for the next 7 d (d 21 to 28) at a constant rate of $1 \mathrm{~L} / \mathrm{d}$, providing $3.35 \mathrm{~g}$ of $\mathrm{Yb}$ per day. The actual amount of marker solution infused each day $(\sim 1 \mathrm{~L})$ was recorded. During each period, a $50-\mathrm{mL}$ subsample of the marker solution that was infused for each cow was collected and stored at room temperature for $\mathrm{Yb}$ analysis. The omasal sampling technique as described by Huhtanen et al. (1997) was used to collect omasal digesta. Briefly, this technique involved locating the omasal canal by hand and then inserting a sampling tube via the ruminal cannula. Sampling tubes were inserted at each sampling time to ensure correct positioning in the omasal canal and to minimize the potential negative effect on digesta passage and normal digestive function if the sampling tubes were left in place between samplings. Once the sampling tube had been inserted in the omasal canal, a 600-mL omasal digesta sample was collected from each cow at 0900,1500 , and $2100 \mathrm{~h}$ on d 26;0300, 1200, and $1800 \mathrm{~h}$ on d 27; and 0000 and $0600 \mathrm{~h}$ on $\mathrm{d} 28$, such that the collected samples were representative of a $24-\mathrm{h}$ feeding cycle. Omasal samples were stored at $-20^{\circ} \mathrm{C}$ and pooled by cow per period over the 24 -h cycle.

To measure ruminal short-chain FA (SCFA) and $\mathrm{NH}_{3}-\mathrm{N}$ concentrations, and bacterial ${ }^{15} \mathrm{~N}$ enrichment, approximately $400 \mathrm{~mL}$ of ruminal digesta was also collected at each omasal sampling time from the cranial ventral, caudal ventral, central, and cranial dorsal rumen through the cannula. The ruminal contents were strained through 4 layers of cheesecloth. Two 10-mL subsamples of ruminal fluid were then collected and mixed with chilled $25 \%$ (wt/vol) meta-phosphoric acid $\left(\mathrm{H}_{2} \mathrm{PO}_{4}\right)$ or $1 \% \mathrm{H}_{2} \mathrm{SO}_{4}$ and stored at $-20^{\circ} \mathrm{C}$ for later determination of SCFA and $\mathrm{NH}_{3}-\mathrm{N}$ contents, respectively. After straining through cheesecloth, the remaining solid digesta was mixed with $500 \mathrm{~mL}$ of $0.15 \mathrm{M}$ saline solution, and homogenized in a blender (NuBlend; Waring Commercial Products, Torrington, CT) for 60 s to dislodge particle-associated bacteria. The blended mixture was squeezed through 4 layers of cheesecloth to obtain a second filtrate. The 2 filtrates were mixed and 375 $\mathrm{mL}$ of the mixture were used to isolate mixed ruminal bacteria by differential centrifugation. Briefly, filtrates were centrifuged at $500 \times g$ for $20 \mathrm{~min}$ at $4^{\circ} \mathrm{C}$ to remove protozoa and residual feed particles. The supernatant was collected and centrifuged at 20,000 $\times g$ for $20 \mathrm{~min}$ at $4^{\circ} \mathrm{C}$ to obtain a ruminal bacterial pellet. Bacterial pellets were then pooled by cow per period and stored at $-20^{\circ} \mathrm{C}$.

To determine ruminal $\mathrm{pH}$, approximately 1,000 mL of ruminal contents were collected from the cranial ventral, caudal ventral, central, and cranial dorsal rumen through the cannula at 0900, 1000, 1100, 1200, 1400, and $1600 \mathrm{~h}$ on $\mathrm{d} 27$. The ruminal contents were strained through 4 layers of cheesecloth. Ruminal fluid $\mathrm{pH}$ was then measured immediately using a model $265 \mathrm{~A}$ portable pH meter (Orion Research Inc., Beverly, MA). At the same time points as for ruminal fluid sampling on $\mathrm{d}$ 27 , blood samples were collected from the contra-lateral jugular vein into $10-\mathrm{mL}$ Vacutainer tubes containing lithium heparin (Becton Dickinson, Franklin Lakes, NJ). The collected samples were centrifuged at 1,500 $\times$ $g$ for $15 \mathrm{~min}$ at $4^{\circ} \mathrm{C}$, and the plasma obtained was stored at $-20^{\circ} \mathrm{C}$ until analyzed for urea-nitrogen (PUN).

Feed intake was recorded daily throughout the experiment. Samples of the TMR and orts were collected from d 23 to 25 and were stored at $-20^{\circ} \mathrm{C}$ for later analysis. Cows were milked 3 times daily at 0430, 1230, and $1900 \mathrm{~h}$, and milk weights were recorded throughout the experiment. Milk samples were collected daily on 3 consecutive days ( $\mathrm{d} 23,24$, and 25 ) from all 3 milkings into vials containing 2-bromo-2-nitropropane-1-2-diol as a preservative. Samples were submitted to the Alberta Central Milk Testing Laboratory (Edmonton, Alberta, Canada) for CP, fat, lactose, and MUN analyses.

\section{Sample Analyses}

After the experiment, frozen TMR and fecal samples were thawed overnight at room temperature, pooled per collection period for each cow, and subsequently dried in an oven at $60^{\circ} \mathrm{C}$ for $48 \mathrm{~h}$ (AOAC, 1990; method 930.15). Dried TMR and fecal samples were then ground through a 1-mm screen using a ChristyNorris mill (Christy and Norris Ltd., Chelmsford, UK). Samples were analyzed for DM (AOAC, 1990; method 930.15), OM (AOAC, 1990; method 942.05), CP using the macro-Kjeldahl procedure (AOAC, 1990; method 976.05), ether extract (AOAC, 1990; method 920.39), and ADF and NDF (Van Soest et al., 1991). Amylase and sodium sulfite were used for NDF determination. Frozen urine samples were thawed overnight at room temperature and then analyzed for $\mathrm{N}$ using the macroKjeldahl procedure (AOAC, 1990; method 976.05). The plasma and dilute urine samples were analyzed for urea- $\mathrm{N}$ by the diacetyl monoxime method (Marsh 
et al., 1957) using a colorimetric urea-N kit (Stanbio Urea Nitrogen Kit, Procedure No. 0580; Stanbio Laboratory, Boerne, TX). Milk samples were analyzed for fat, CP, lactose, and MUN using infrared spectroscopy (MilkoScan 605; Foss Electric A/S, Hillerød, Denmark; AOAC, 1990; method 972.16).

To determine the enrichments of $\left[{ }^{15} \mathrm{~N}^{15} \mathrm{~N}\right]$ - and $\left[{ }^{14} \mathrm{~N}^{15} \mathrm{~N}\right]$-urea in daily urine samples (50-mL subsample), urinary urea- $\mathrm{N}$ was isolated by passing urine containing $1.5 \mathrm{mg}$ of urea- $\mathrm{N}$ through a prepacked cation-exchange resin column (AG-50W- $\times 8$ resin, 100-200 mesh, $\mathrm{H}^{+}$ form; Bio-Rad Laboratories Inc., Richmond, CA) as described by Archibeque et al. (2001). Following application of urine, $7 \mathrm{~mL}$ of $\mathrm{N}$-free water was added to the column before elution of urea- $\mathrm{N}$ into test tubes using $20 \mathrm{~mL}$ of $\mathrm{N}$-free water. Following air drying $\left(60^{\circ} \mathrm{C}\right)$ of the eluate, three $1-\mathrm{mL}$ rinses of $\mathrm{N}$-free water were used to quantitatively transfer urea- $\mathrm{N}$ from the test tubes into $17 \times 60-\mathrm{mm}$ borosilicate glass tubes. Subsequently, the urea-N samples were freeze dried and analyzed for $\left[{ }^{15} \mathrm{~N}^{15} \mathrm{~N}\right]$ - and $\left[{ }^{14} \mathrm{~N}^{15} \mathrm{~N}\right]$-urea enrichment by isotope ratiomass spectrometry (IRMS; N-15 Analysis Laboratory, University of Illinois, Urbana-Champaign) as described by Lobley et al. (2000). Analytical conditions used during IRMS should lead to the production of ions with mass/charge $(\mathrm{m} / \mathrm{z})$ values of 28,29 , and 30 for $\left.\left[{ }^{14} \mathrm{~N}^{14} \mathrm{~N}\right]-,{ }^{14} \mathrm{~N}^{15} \mathrm{~N}\right]$ - and $\left[{ }^{15} \mathrm{~N}^{15} \mathrm{~N}\right]$-urea, respectively. Standards prepared using $\left[{ }^{15} \mathrm{~N}^{15} \mathrm{~N}\right]$-urea $\left(99.8\right.$ atom $\%{ }^{15} \mathrm{~N}$ ) and $\left[{ }^{14} \mathrm{~N}^{14} \mathrm{~N}\right]$-urea (natural abundance urea; 0.364 atom $\%{ }^{15} \mathrm{~N}$ ) were also analyzed, and results used to correct for $\left[{ }^{14} \mathrm{~N}^{15} \mathrm{~N}\right]$-urea produced during non-monomolecular reactions (Lobley et al., 2000). Daily fecal samples were thawed overnight at room temperature before DM analysis (AOAC, 1990; method 930.15). Dried fecal samples were subsequently ground through a 1-mm screen using a Christy-Norris mill (Christy and Norris Ltd.) and were analyzed for ${ }^{15} \mathrm{~N}$ enrichment by combustion to $\mathrm{N}_{2}$ gas in an elemental analyzer and continuous-flow IRMS (Lobley et al., 2000).

In preparation for NAN and ${ }^{15} \mathrm{~N}$ analyses, the omasal ${ }^{15} \mathrm{NB}$ and bacterial pellet samples were freeze dried. Freeze-dried ${ }^{15} \mathrm{NB}$ samples were then ground through a 1-mm screen (Christy-Norris Ltd.) before being pulverized with a ball mill. Freeze-dried bacterial pellet samples were ground using a mortar and pestle. The composited omasal digesta samples were freeze dried and ground through a 1-mm screen using a ChristyNorris mill (Christy and Norris Ltd.). To determine $\mathrm{Yb}$ concentration, a $1-\mathrm{g}$ sample was combusted at $550^{\circ} \mathrm{C}$ for $8 \mathrm{~h}$ in a muffle furnace (AOAC, 1990) before nitric acid digestion, as described by Vicente et al. (2004). Subsequently, $\mathrm{Yb}$ concentration was measured by atomic absorption spectrophotometry (PerkinElmer 2300; PerkinElmer Corp., Norwalk, CT). The Yb concentration in omasal digesta was then used to determine omasal DM flow (France and Siddons, 1986). To determine the flow of nutrients to the omasum, the freeze-dried omasal digesta samples were analyzed for $\mathrm{OM}$ by combustion in a muffle furnace at $550^{\circ} \mathrm{C}$ for $8 \mathrm{~h}$, total $\mathrm{N}$ (Leco 2000; Leco Instruments Inc., St. Joseph, MI), ADF, and NDF. To quantify $\mathrm{NH}_{3}-\mathrm{N}, 10 \mathrm{~mL}$ of $0.07 M$ sodium citrate $(\mathrm{pH} 2.2)$ was added to $0.5 \mathrm{~g}$ of omasal digesta and the mixture vortexed and subsequently held at $39^{\circ} \mathrm{C}$ for $30 \mathrm{~min}$ in a forced-air oven. The extracts were then centrifuged at $18,000 \times g$ for $15 \mathrm{~min}$ at $4^{\circ} \mathrm{C}$, and the resultant supernatant was analyzed for $\mathrm{NH}_{3}-\mathrm{N}$ using the phenol-hypochlorite method as described by Broderick and Kang (1980). Samples of ${ }^{15} \mathrm{NB}$, bacterial pellets, and omasal digesta were prepared for ${ }^{15} \mathrm{~N}$ analysis as described by Brito et al. (2009). Briefly, to volatize $\mathrm{NH}_{3}-\mathrm{N}$ before ${ }^{15} \mathrm{~N}$ analysis, ${ }^{15} \mathrm{NB}$, bacterial pellets, and omasal digesta, samples containing approximately $100 \mu \mathrm{g}$ of $\mathrm{N}$ were weighed into $5 \times 9$-mm tin capsules (Elemental Microanalysis Ltd., Okehampton, UK). Subsequently, $50 \mu \mathrm{L}$ of $72 \mathrm{mM} \mathrm{K} \mathrm{CO}_{3}$ was added to each capsule before incubation in a forced-air oven at $60^{\circ} \mathrm{C}$ for $24 \mathrm{~h}$. Enrichment of ${ }^{15} \mathrm{~N}$ in $\mathrm{NAN}$ of the samples was then measured by combustion to $\mathrm{N}_{2}$ gas in an elemental analyzer and continuous-flow IRMS. Bacterial pellets were analyzed for OM by combustion in a muffle furnace at $550^{\circ} \mathrm{C}$ for at $8 \mathrm{~h}$.

Frozen ruminal fluid samples were thawed at room temperature and pooled by cow for each period. This was followed by centrifugation at $20,000 \times g$ for 15 min at $4^{\circ} \mathrm{C}$ to obtain a clear supernatant. For ruminal fluid samples that were preserved with $25 \% \mathrm{H}_{2} \mathrm{PO}_{4}$, supernatants were filtered through a $0.45-\mu \mathrm{m}$ membrane and a $0.9-\mathrm{mL}$ portion of the filtered supernatant was mixed with $0.1 \mathrm{~mL}$ of $10 \mathrm{mg} / \mathrm{mL}$ crotonic acid as an internal standard. Ruminal SCFA were then separated and quantified by gas chromatography (Agilent 6890; Agilent Technologies Canada Inc., Mississauga, ON, Canada) as described by Erwin et al. (1961). For ruminal fluid samples that were preserved with $\mathrm{H}_{2} \mathrm{SO}_{4}$, supernatants were analyzed for ruminal $\mathrm{NH}_{3}-\mathrm{N}$ using a phenol-hypochlorite assay (Broderick and Kang, 1980).

\section{Calculations and Statistical Analyses}

Urinary ${ }^{15} \mathrm{~N}$ enrichment of $\left[{ }^{15} \mathrm{~N}^{15} \mathrm{~N}\right]$ - and $\left[{ }^{14} \mathrm{~N}^{15} \mathrm{~N}\right]$-urea and total fecal ${ }^{15} \mathrm{~N}$ excretion were used to calculate urea-N kinetics using the model described by Lobley et al. (2000). Based on this model, a fraction of urea-N synthesized in the liver (urea-N entry rate, UER) is irreversibly lost in urine (urinary urea-N elimination), whereas the remaining fraction is recycled to the GIT (GIT entry rate, GER). Urea-N recycled to the GIT is hydrolyzed by bacterial urease to $\mathrm{NH}_{3}-\mathrm{N}$, which 
has 3 fates: (1) excretion in feces (urea- $\mathrm{N}$ in feces); (2) reabsorption into portal blood and reentry into the ornithine cycle (ROC), resulting in the formation of 3 urea-N species (i.e., $\left[{ }^{14} \mathrm{~N}^{14} \mathrm{~N}\right]-,\left[{ }^{14} \mathrm{~N}^{15} \mathrm{~N}\right]-$, and $\left[{ }^{15} \mathrm{~N}^{15} \mathrm{~N}\right]-$ urea); or (3) utilization for anabolic purposes (UUA), which is assumed to be primarily ruminal microbial protein synthesis (Lobley et al., 2000).

Omasal true digesta NAN content was calculated as total $\mathrm{N}-\mathrm{NH}_{3}-\mathrm{N}$. Omasal digesta and bacterial pellet ${ }^{15} \mathrm{~N}$ enrichment (APE) was calculated as follows: ${ }^{15} \mathrm{~N}$ $\mathrm{APE}=$ sample ${ }^{15} \mathrm{~N}$ percentage - mean background sample ${ }^{15} \mathrm{~N}$ percentage. Bacterial NAN flow was then calculated by multiplying omasal NAN flow by the ratio of omasal digesta ${ }^{15} \mathrm{~N}$ enrichment to bacterial pellet ${ }^{15} \mathrm{~N}$ enrichment (Wickersham et al., 2009a). The omasal flow of bacterial NAN that was derived from recycled urea- $\mathrm{N}$ was calculated as bacterial NAN flow $\times$ (bacterial ${ }^{15} \mathrm{~N}$ enrichment $\div$ urinary ${ }^{15} \mathrm{~N}$ enrichment) (Wickersham et al., 2009a). Apparent ruminal nutrient digestibilities were calculated as nutrient intake - omasal flow of nutrient, with flows expressed as kilograms per day (Reynal and Broderick, 2005). Organic matter truly digested in the rumen was determined as OM intake - (omasal OM flow - microbial OM flow). Omasal flow of nonammonia nonmicrobial N (NANMN), RUP, and RDP were also calculated as described by Reynal and Broderick (2005) as follows: NANMN flow $=$ total $\mathrm{NAN}$ flow - microbial NAN flow, RUP flow $=$ total $\mathrm{CP}$ flow - microbial CP flow, and RDP supply $=$ total CP intake - RUP flow.

All data on ruminal fermentation parameters, nutrient digestibilities, omasal flow, and excretion, and urea- $\mathrm{N}$ kinetics were analyzed as a $4 \times 4$ Latin square using PROC MIXED of SAS (SAS Institute, 2004). Production data for the 8 cows were also analyzed using PROC MIXED of SAS for a replicated $4 \times 4$ Latin square design. The models included the following independent variables: cow, period, type of distillers co-product (W-DDGS vs. B-DDGS), dietary CP content (low $[15.2 \%]$ vs. high [17.3\%]), and the type of distillers co-product $\times$ dietary $\mathrm{CP}$ content interaction. Period and dietary treatment were considered as fixed, whereas cow was considered as random. For dependent variables that had repeated measurements (ruminal $\mathrm{pH}$ and PUN concentrations), the repeated measures option within PROC MIXED of SAS (SAS Institute, 2004) was used. Treatment differences were considered significant when $P \leq 0.05$ and tendencies when $0.05<$ $P \leq 0.10$. Interactions between dietary $\mathrm{CP}$ content and type of distillers co-product were not detected for most of the major variables that were measured (see Tables 2 to 7), so only main effects are presented and discussed.

\section{RESULTS}

\section{Dietary Characteristics}

Dietary ingredient and chemical composition are presented in Table 1. Experimental diets were formulated to contain 15 or $17 \% \mathrm{CP}$ (DM basis) and chemical analysis showed only marginal maximum deviations $(+0.3$ and +0.4 percentage units, respectively) from the intended dietary $\mathrm{CP}$ contents (Table 1 ).

\section{Production Parameters}

Results on feed intake and milk production that are presented in Table 2 are from all 8 cows that were used in the study. Dietary CP content and type of distillers co-product had no effects $(P \geq 0.29)$ on DMI. Cows fed the high-CP diet had greater $(P<0.01) \mathrm{N}$ intakes compared with those fed the low-CP diet (Table 2). Cows fed the high-CP diet had greater $(P<0.01)$ milk yield, ECM yield, and feed efficiency compared with those fed the low-CP diet. However, dietary CP content and type of distillers co-product had no effects milk $\mathrm{N}$ efficiency $(P>0.05)$. No effects $(P>0.05)$ were observed of dietary $\mathrm{CP}$ content and type of distillers co-product on milk fat and lactose contents, but milk protein content was higher $(P=0.03)$ in cows fed the high- compared with those fed the low-CP diet. Feeding the high-CP diet also resulted in greater $(P<0.01)$ milk fat, protein, and lactose yields, and greater MUN and PUN concentrations compared with feeding the low-CP diet.

\section{Ruminal Fermentation Characteristics}

Feeding the high-CP diet resulted in a higher $(P$ $=0.04)$ ruminal $\mathrm{NH}_{3}-\mathrm{N}$ concentration compared with feeding the low-CP diet (Table 3$)$. No effects $(P>0.05)$ were observed of dietary $\mathrm{CP}$ content and type of distillers co-product on ruminal total SCFA concentration, molar proportions of propionate, butyrate, and valerate, and acetate:propionate ratio. Ruminal concentration of total branched-chain FA (BCFA; $P<0.01)$ and molar proportions of isobutyrate $(P=0.03)$ and isovalerate $(P=0.008)$ were higher, whereas the molar proportion of acetate $(P=0.07)$ tended to be lower in cows fed the high-CP compared with those fed the low-CP diet. Also, the molar proportion of isovalerate was higher $(P=0.047)$ in cows fed B-DDGS compared with those fed W-DDGS. No effects $(P \geq 0.14)$ were observed of dietary $\mathrm{CP}$ content and type of distillers co-product on ruminal $\mathrm{pH}$. 
Table 2. Dry matter intake and milk yield and composition of cows fed low- or high-CP diets containing either wheat-based dried distillers grains with solubles (W-DDGS) or wheat-corn blend DDGS (B-DDGS) as the major protein source $(\mathrm{n}=8)$

\begin{tabular}{|c|c|c|c|c|c|c|c|c|}
\hline \multirow[b]{2}{*}{ Variable } & \multicolumn{2}{|c|}{ Low-CP diet } & \multicolumn{2}{|c|}{ High-CP diet } & \multirow[b]{2}{*}{ SEM } & \multicolumn{3}{|c|}{$P$-value ${ }^{1}$} \\
\hline & W-DDGS & B-DDGS & W-DDGS & B-DDGS & & $\mathrm{CP}$ & DDGS & $\mathrm{CP} \times \mathrm{DDGS}$ \\
\hline $\mathrm{N}$ intake $(\mathrm{g} / \mathrm{d})$ & 684 & 713 & 805 & 814 & 21.4 & $<0.01$ & 0.17 & 0.49 \\
\hline Milk yield (kg/d) & 39.5 & 41.0 & 44.1 & 43.7 & 1.53 & $<0.01$ & 0.52 & 0.28 \\
\hline $\operatorname{ECM}^{2}(\mathrm{~kg} / \mathrm{d})$ & 43.8 & 45.2 & 48.5 & 48.0 & 1.86 & $<0.01$ & 0.60 & 0.29 \\
\hline Feed efficiency ${ }^{3}$ & 1.39 & 1.42 & 1.52 & 1.50 & 0.044 & 0.01 & 0.93 & 0.55 \\
\hline Milk fat yield $(\mathrm{kg} / \mathrm{d})$ & 1.40 & 1.45 & 1.56 & 1.56 & 0.055 & $<0.01$ & 0.45 & 0.37 \\
\hline Milk protein $(\%)$ & 3.08 & 3.12 & 3.19 & 3.24 & 0.102 & 0.03 & 0.45 & 0.90 \\
\hline Milk protein yield $(\mathrm{kg} / \mathrm{d})$ & 1.19 & 1.25 & 1.36 & 1.35 & 0.049 & $<0.01$ & 0.57 & 0.41 \\
\hline Milk lactose (\%) & 4.61 & 4.56 & 4.59 & 4.62 & 0.036 & 0.49 & 0.68 & 0.13 \\
\hline Milk lactose yield $(\mathrm{kg} / \mathrm{d})$ & 1.79 & 1.84 & 1.97 & 1.95 & 0.089 & $<0.01$ & 0.79 & 0.42 \\
\hline MUN (mg/dL) & 12.9 & 12.3 & 14.8 & 15.0 & 0.79 & $<0.01$ & 0.73 & 0.56 \\
\hline $\mathrm{PUN}^{5}(\mathrm{mg} / \mathrm{dL})$ & 16.3 & 15.4 & 18.5 & 19.5 & 1.12 & $<0.01$ & 0.95 & 0.16 \\
\hline
\end{tabular}

${ }^{1} P$-values are for $\mathrm{CP}$ content, source of DDGS, and CP $\times$ DDGS interaction.

${ }^{2}$ Energy-corrected milk $=[0.327 \times$ milk yield $(\mathrm{kg})]+[12.95 \times$ fat yield $(\mathrm{kg})]+[7.2 \times$ protein yield $(\mathrm{kg})](\mathrm{Orth}, 1992)$.

${ }^{3}$ Feed efficiency $=$ ECM $/$ DMI.

${ }^{4}$ Nitrogen efficiency $=$ milk $\mathrm{N}(\mathrm{kg} / \mathrm{d}) / \mathrm{N}$ intake $(\mathrm{kg} / \mathrm{d})$.

${ }^{5}$ Plasma urea-N.

\section{Ruminal Digestion and Nutrient Flow}

No effects $(P>0.05)$ were observed of dietary CP content and type of distillers co-product on intakes and omasal flows of DM and OM (Table 4); however, the amount of OM truly digested in the rumen tended to be greater $(P=0.09)$ for cows fed the high-CP compared with those fed the low-CP diet. Intake of NDF $(P=0.08)$ and the amount of NDF apparently digested in the rumen $(P=0.09)$ tended to be lower for cows fed the high-CP compared with those fed the low-CP diet. Intake of $\operatorname{ADF}(P=0.03)$ was lower in cows fed the high-CP compared with those fed the low-CP diet.
Also, intake of $\operatorname{ADF}(P=0.06)$ tended to be lower in cows fed B-DDGS compared with those fed W-DDGS; however, ruminal digestion and omasal flow of $\mathrm{ADF}$ was not affected by dietary CP content and type of distillers co-product.

\section{Intake, Digestibility, and Omasal Flow of Nitrogen Fractions}

Cows fed the low-CP diet consumed less $\mathrm{N}(P<$ 0.01) compared with those fed the high-CP diet (Table 5 ); however, $\mathrm{N}$ apparently digested in the rumen, when

Table 3. Ruminal fermentation characteristics of cows fed low- or high-CP diets containing either wheat-based dried distillers grains with solubles (W-DDGS) or wheat-corn blend DDGS (B-DDGS) as the major protein source $(\mathrm{n}=4)$

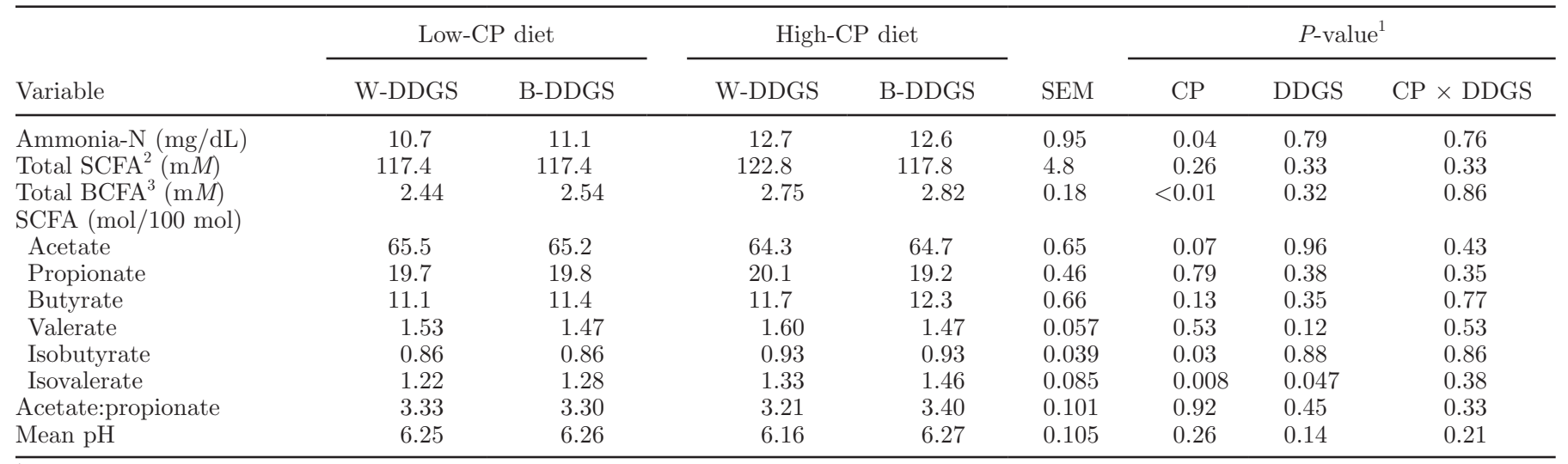

${ }^{1} P$-values are for $\mathrm{CP}$ content, source of DDGS, and CP $\times$ DDGS interaction.

${ }^{2} \mathrm{SCFA}=$ short-chain $\mathrm{FA}$.

${ }^{3} \mathrm{BCFA}=$ branched-chain FA. 
Table 4. Nutrient flow from and digestion in the rumen of cows fed low- or high-CP diets containing either wheat-based dried distillers grains with solubles (W-DDGS) or wheat-corn blend DDGS (B-DDGS) as the major protein source $(\mathrm{n}=4)$

\begin{tabular}{|c|c|c|c|c|c|c|c|c|}
\hline \multirow[b]{2}{*}{ Variable } & \multicolumn{2}{|c|}{ Low-CP diet } & \multicolumn{2}{|c|}{ High-CP diet } & \multirow[b]{2}{*}{ SEM } & \multicolumn{3}{|c|}{$P$-value ${ }^{1}$} \\
\hline & W-DDGS & B-DDGS & W-DDGS & B-DDGS & & $\mathrm{CP}$ & DDGS & $\mathrm{CP} \times \mathrm{DDGS}$ \\
\hline \multicolumn{9}{|l|}{$\mathrm{DM}$} \\
\hline Intake $(\mathrm{kg} / \mathrm{d})$ & 27.8 & 27.5 & 28.7 & 28.4 & 0.87 & 0.15 & 0.68 & 0.96 \\
\hline Omasal flow $(\mathrm{kg} / \mathrm{d})$ & 21.4 & 20.4 & 22.4 & 22.0 & 0.96 & 0.17 & 0.47 & 0.72 \\
\hline Apparent digestion $(\mathrm{kg} / \mathrm{d})$ & 6.43 & 7.14 & 6.28 & 6.42 & 0.48 & 0.37 & 0.38 & 0.54 \\
\hline Apparent digestion (\% of DMI) & 23.1 & 26.1 & 22.0 & 22.4 & 1.76 & 0.21 & 0.37 & 0.48 \\
\hline Omasal flow $(\mathrm{kg} / \mathrm{d})$ & 19.2 & 18.4 & 20.6 & 20.0 & 0.96 & 0.12 & 0.42 & 0.93 \\
\hline Apparent digestion $(\mathrm{kg} / \mathrm{d})$ & 6.83 & 7.49 & 6.29 & 6.81 & 0.63 & 0.32 & 0.33 & 0.91 \\
\hline Apparent digestion (\% of OM intake) & 26.2 & 29.1 & 23.4 & 25.2 & 2.36 & 0.19 & 0.35 & 0.81 \\
\hline True digestion (kg/d) & 13.6 & 14.4 & 15.2 & 14.5 & 0.60 & 0.09 & 0.94 & 0.14 \\
\hline True digestion (\% of OM intake) & 52.4 & 55.8 & 56.7 & 54.1 & 1.93 & 0.52 & 0.82 & 0.14 \\
\hline \multicolumn{9}{|l|}{ NDF } \\
\hline Intake $(\mathrm{kg} / \mathrm{d})$ & 9.93 & 9.65 & 9.40 & 9.31 & 0.26 & 0.08 & 0.42 & 0.67 \\
\hline Omasal flow $(\mathrm{kg} / \mathrm{d})$ & 2.88 & 2.45 & 2.70 & 2.71 & 0.26 & 0.84 & 0.32 & 0.29 \\
\hline Apparent digestion $(\mathrm{kg} / \mathrm{d})$ & 2.62 & 2.71 & 2.39 & 2.16 & 0.27 & 0.03 & 0.63 & 0.29 \\
\hline Apparent digestion (\% of ADF intake) & 47.4 & 52.5 & 47.2 & 44.1 & 4.88 & 0.21 & 0.75 & 0.24 \\
\hline
\end{tabular}

${ }^{1} P$-values are for $\mathrm{CP}$ content, source of DDGS, and $\mathrm{CP} \times$ DDGS interaction.

expressed as grams per day or as a proportion of $\mathrm{N}$ intake, did not differ $(P>0.05)$ with dietary CP content and type of distillers co-product. The absolute amount of $\mathrm{N}$ truly digested in the rumen was higher $(P=0.03)$ in cows fed the high-CP compared with the low-CP diet. The supply of RDP, when expressed as grams per day or as a proportion of DMI, was higher $(P=0.03)$ when cows were fed the high-CP compared with the low-CP diet. Similarly, the amounts of N $(P=0.02)$ and total NAN $(P=0.03)$ flowing at the omasal canal were higher, whereas $\mathrm{NH}_{3}-\mathrm{N}$ flow tended to be higher $(P=0.06)$ in cows fed the high-CP compared with those fed the low-CP diet. No effects $(P>0.05)$ were observed of dietary $\mathrm{CP}$ content and type of distillers co-product on omasal flows of non- $\mathrm{NH}_{3}$ nonbacterial $\mathrm{N}$ and RUP. When cows were fed the high-CP compared with the low-CP diet, omasal flow of bacterial NAN $(\mathrm{g} / \mathrm{d})$ tended to be higher $(P=0.09)$. The efficiency of microbial protein synthesis was unaffected $(P>0.05)$ by dietary $\mathrm{CP}$ content and type of distillers co-product. The type of distillers co-product did not influence omasal flows of bacterial NAN or total NAN.

\section{Nitrogen Balance and Apparent Total-Tract Nutrient Digestibilities}

Cows fed the high-CP diet had greater $\mathrm{N}$ intake $(P$ $<0.01)$ and milk $\mathrm{N}$ content $(P=0.04)$ compared with those fed the low-CP diet (Table 6). Urinary $\mathrm{N}$ and total $\mathrm{N}$ excretion were also higher $(P<0.01)$ in cows fed the high-CP compared with the low-CP diet. Although fecal $\mathrm{N}$ excretion did not differ $(P>0.05)$, fecal $\mathrm{N}$ excretion expressed as a percentage of $\mathrm{N}$ intake was greater $(P<0.01)$ on the low- compared with the high$\mathrm{CP}$ diet. No effects $(P>0.05)$ were observed of dietary $\mathrm{CP}$ content and type of distillers co-product on apparent $\mathrm{N}$ balance. Apparent total-tract $\mathrm{N}$ digestibility was higher $(P<0.01)$, and apparent total-tract DM $(P=$ $0.10)$ and $\mathrm{OM}(P=0.07)$ digestibilities tended to be higher when cows were fed the high-CP compared with the low-CP diet. Apparent total-tract N digestibility tended to be higher $(P=0.06)$ in cows fed B-DDGS compared with those fed W-DDGS. Apparent totaltract NDF, ADF, and fat digestibilities were unaffected $(P>0.05)$ by dietary $\mathrm{CP}$ content and type of distillers co-product.

\section{Urea-N Recycling Kinetics}

Urea-N synthesis (i.e., UER), urea-N loss in urine (urinary urea- $\mathrm{N}$ elimination), and urea- $\mathrm{N}$ returned to the ornithine cycle $(\mathrm{ROC})$ were higher $(P \leq 0.05)$ in cows fed the high-CP compared with those fed the low$\mathrm{CP}$ diet (Table 7). Urea-N that was transferred to the GIT (GER) tended to be higher $(P=0.06)$ in cows fed the high-CP diet compared with those fed the low-CP diet. No effects $(P>0.05)$ were observed of dietary $\mathrm{CP}$ content and type of distillers co-product on the 
Table 5. Intake, digestibility, and omasal flow of N constituents in cows fed low- or high-CP diets containing either wheat-based dried distillers grains with solubles (W-DDGS) or wheat-corn blend DDGS (B-DDGS) as the major protein source $(\mathrm{n}=4)$

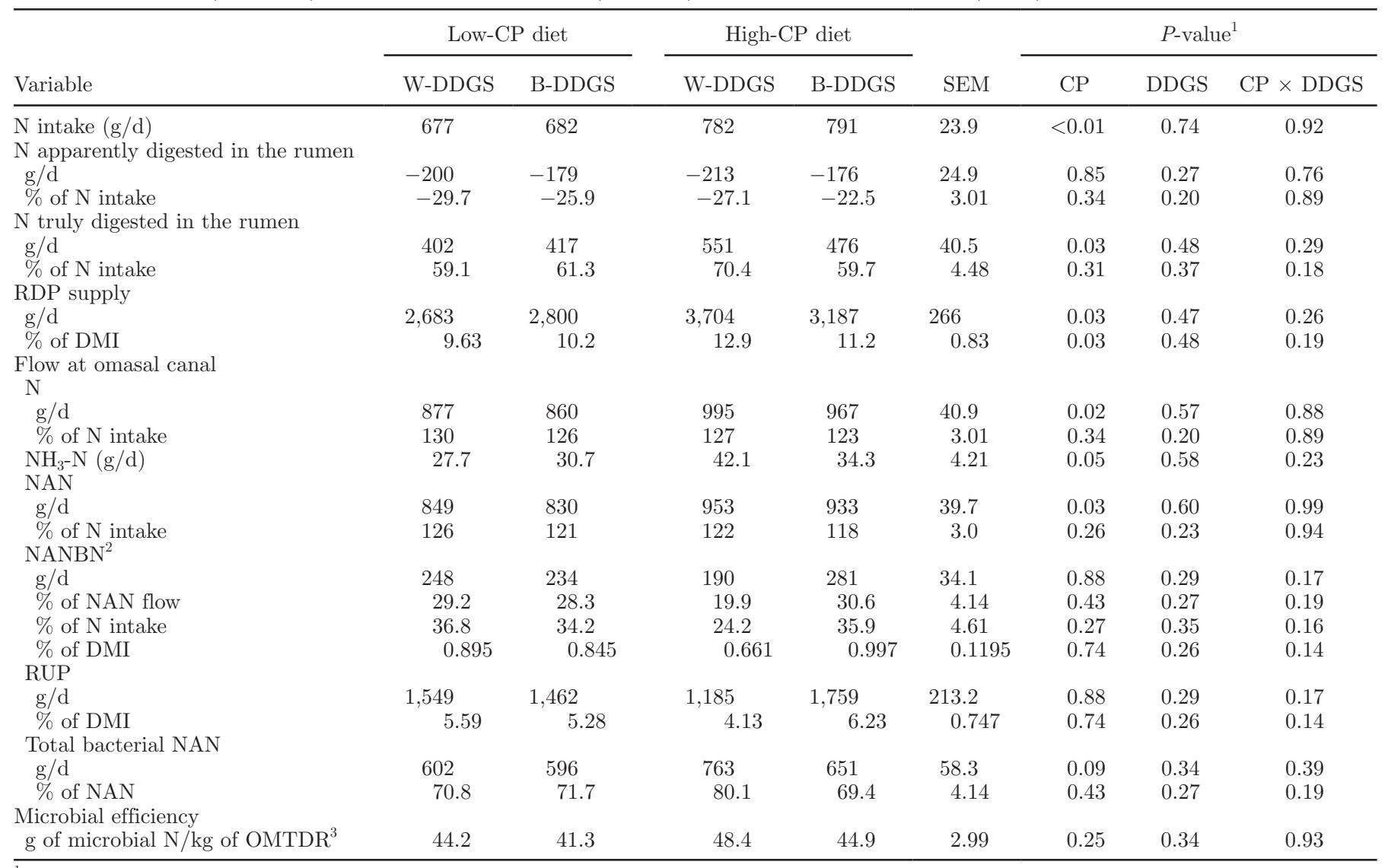

${ }^{1} P$-values are for CP content, source of DDGS, and CP $\times$ DDGS interaction.

${ }^{2} \mathrm{NANBN}=$ non- $\mathrm{NH}_{3}$ nonbacterial $\mathrm{N}$.

${ }^{3} \mathrm{OMTDR}=\mathrm{OM}$ truly digested in the rumen.

quantity of urea-N that was used for anabolic purposes (UUA) or lost in feces (urea-N excretion in feces). Dietary $\mathrm{CP}$ content and type of distillers co-product had no effects $(P>0.05)$ on fractional urea-N transfers, but the proportion of GER that was lost in feces tended to be higher $(P=0.07)$ in cows fed the low- compared with those fed the high-CP diet. The amount of recycled urea- $\mathrm{N}$ that was incorporated into microbial $\mathrm{N}$ (g/d) was unaffected by dietary CP content and type of distillers co-product; however, when expressed as a percentage of total microbial NAN, the proportion of recycled urea-N that was incorporated into microbial $\mathrm{N}$ was greater $(P=0.02)$ on the low-CP compared with the high-CP diet.

\section{DISCUSSION}

Altering dietary $\mathrm{CP}$ content had major effects on $\mathrm{N}$ utilization, which were largely reflective of the difference in $\mathrm{N}$ intake, as has been reported by others (Olmos Col- menero and Broderick, 2006a; Brito et al., 2007, 2009). The amount of dietary $\mathrm{N}$ that was apparently digested in the rumen was negative for all diets, indicating that omasal $\mathrm{N}$ flow was greater than $\mathrm{N}$ intake. Broderick et al. (2010) reported that zero ruminal $\mathrm{N}$ balance (with ruminal $\mathrm{N}$ balance calculated as omasal $\mathrm{N}$ flow - $\mathrm{N}$ intake) occurred when dietary $\mathrm{CP}$ and RDP contents were approximately 14.7 and approximately $10.6 \%$, respectively, and that ruminal $\mathrm{N}$ balance became positive as dietary $\mathrm{CP}$ and RDP contents increased. In the present study, dietary CP and RDP contents were $\geq 15$ and $\geq 9.9 \%$, respectively, so ruminal $\mathrm{N}$ balance would be expected to be largely positive. Others (Reynal et al., 2003; Olmos Colmenero and Broderick, 2006a) have also reported negative apparent $\mathrm{N}$ digestion in the rumen in dairy cows. Broderick et al. (2008) attributed the positive ruminal $\mathrm{N}$ balance to the $\mathrm{N}$ contribution of recycled urea- $\mathrm{N}$ to the ruminal $\mathrm{NH}_{3}-\mathrm{N}$ pool and its subsequent utilization for microbial protein synthesis. In the present study, urea-N entry to the GIT was 
Table 6. Nitrogen balance and apparent total-tract nutrient digestibility in cows fed low- or high-CP diets containing either wheat-based dried distillers grains with solubles (W-DDGS) or wheat-corn blend DDGS (B-DDGS) as the major protein source $(\mathrm{n}=4)$

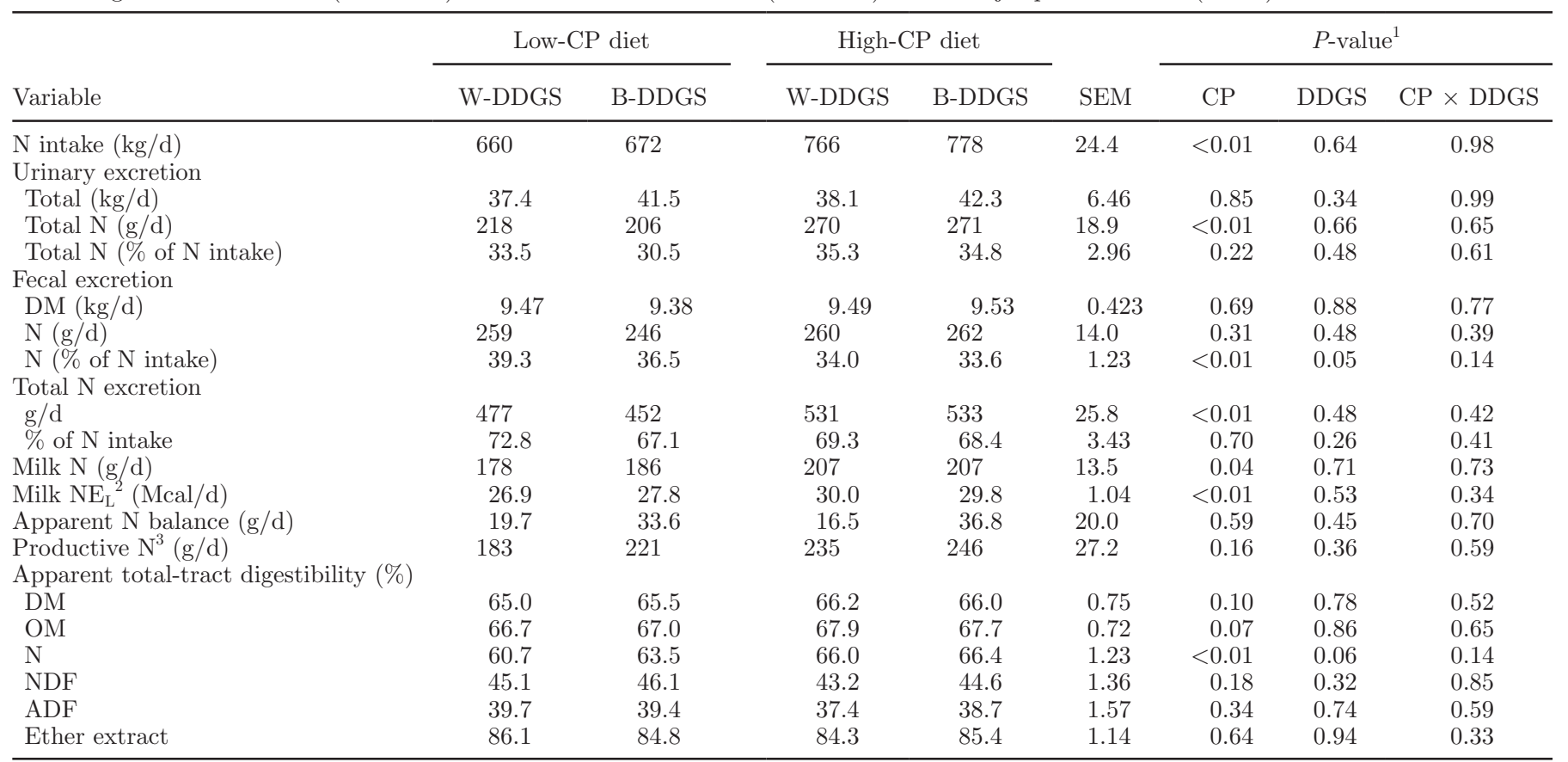

${ }^{1} P$-values are for CP content, source of DDGS, and CP $\times$ DDGS interaction.

${ }^{2} \mathrm{Milk} \mathrm{NE}_{\mathrm{L}}(\mathrm{Mcal} / \mathrm{d})=\mathrm{kg}$ of milk $\times(0.0929 \times \%$ fat $+0.0563 \times \%$ true protein $+0.0395 \times \%$ lactose $)(\mathrm{NRC}, 2001)$.

${ }^{3}$ Calculated as $\mathrm{N}$ secreted in milk plus $\mathrm{N}$ apparently retained by the cow.

substantial, ranging from 328 to $383 \mathrm{~g} / \mathrm{d}$, so it is not surprising that ruminal $\mathrm{N}$ balance was positive.

When expressed in absolute amounts $(+704 \mathrm{~g} / \mathrm{d})$ or as a proportion of DMI (+2.2 percentage units), RDP supply was greater in cows fed the high-CP diet compared with those fed the low-CP diet. This was expected because, for a given diet, the amount of $\mathrm{CP}$ that is degraded in the rumen (i.e., RDP) increases as dietary CP content increases (Olmos Colmenero and Broderick, 2006b). The lower RDP supply resulted in

Table 7. Urea-N recycling kinetics in cows fed low- or high-CP diets containing either wheat-based dried distillers grains with solubles (W-DDGS) or wheat-corn blend DDGS (B-DDGS) as the major protein source $(\mathrm{n}=4)$

\begin{tabular}{|c|c|c|c|c|c|c|c|c|}
\hline Variable $^{1}$ & \multicolumn{2}{|c|}{ Low-CP diet } & \multicolumn{2}{|c|}{ High-CP diet } & SEM & \multicolumn{3}{|c|}{$P$-value ${ }^{2}$} \\
\hline \multicolumn{9}{|l|}{ Urea-N kinetics (g/d) } \\
\hline Entry to GIT, GER & 347 & 308 & 390 & 375 & 24.1 & 0.06 & 0.31 & 0.64 \\
\hline Return to ornithine cycle (ROC) & 247 & 214 & 280 & 261 & 16.7 & 0.05 & 0.18 & 0.69 \\
\hline Loss to feces, UFE & 14.3 & 14.0 & 14.8 & 13.9 & 0.89 & 0.82 & 0.54 & 0.77 \\
\hline \multicolumn{9}{|l|}{ Fractional urea-N transfers } \\
\hline UER to urine & 0.195 & 0.197 & 0.228 & 0.232 & 0.0190 & 0.12 & 0.88 & 0.97 \\
\hline UER to GIT & 0.805 & 0.803 & 0.772 & 0.768 & 0.0191 & 0.12 & 0.88 & 0.97 \\
\hline GER to ROC & 0.715 & 0.694 & 0.717 & 0.699 & 0.0121 & 0.80 & 0.17 & 0.90 \\
\hline GER to feces & 0.041 & 0.045 & 0.038 & 0.038 & 0.0024 & 0.07 & 0.47 & 0.36 \\
\hline GER to UUA & 0.243 & 0.260 & 0.245 & 0.262 & 0.0132 & 0.88 & 0.25 & 0.96 \\
\hline \multicolumn{9}{|l|}{ Ruminal microbial capture of recycled $\mathrm{N}$} \\
\hline
\end{tabular}

${ }^{1} \mathrm{UER}=$ urea-N entry rate; GIT $=$ gastrointestinal tract; GER = GIT entry rate; UFE = urea-N excretion in feces; UUE $=$ urinary urea-N elimination; UUA = utilization for anabolic purposes.

${ }^{2} P$-values are for $\mathrm{CP}$ content, source of DDGS, and $\mathrm{CP} \times$ DDGS interaction. 
lower ruminal $\mathrm{NH}_{3}-\mathrm{N}$ concentrations in cows that were fed the low-CP compared with those fed the high-CP diet. It has been suggested that a ruminal $\mathrm{NH}_{3}-\mathrm{N}$ concentration between 11.0 and $11.8 \mathrm{mg} / \mathrm{dL}$ is required to support maximum microbial protein synthesis (Balcells et al., 1993; Reynal and Broderick, 2005). In the present study, ruminal $\mathrm{NH}_{3}-\mathrm{N}$ concentration on the $15.2 \% \mathrm{CP}$ diet was below this threshold by $>20 \%$. The ruminal deficiency of $\mathrm{NH}_{3}-\mathrm{N}$ could have suppressed microbial growth in cows fed the low-CP diet, such that the omasal flow of microbial NAN was $108 \mathrm{~g} / \mathrm{d}$ lower compared with cows fed the high-CP diet. Olmos Colmenero and Broderick (2006b) also reported a lower microbial NAN flow as dietary CP content was lowered from 19.4 to $13.5 \%$. The choice of W-DDGS or B-DDGS as the major source of dietary protein had no influence on omasal flows of microbial NAN and $\mathrm{N}$ fractions. Intakes of $\mathrm{N}$ were similar in cows fed W-DDGS and B-DDGS, so it is not surprising that total $\mathrm{N}$ flow at the omasal canal was similar because it is primarily dictated by $\mathrm{N}$ intake (Reynal and Broderick, 2005; Olmos Colmenero and Broderick, 2006b). Our results show that no differences existed in RDP supply or ruminal $\mathrm{NH}_{3}-\mathrm{N}$ concentration when W-DDGS or B-DDGS were fed as the major sources of protein. As ruminal $\mathrm{NH}_{3}-\mathrm{N}$ availability has a major influence on microbial growth, it is not surprising that the omasal flow of microbial NAN was unaffected by source of dietary protein. Across dietary treatments, omasal flow of $\mathrm{NH}_{3}-\mathrm{N}$ accounted for only 3 to $4 \%$ of omasal flow of total $\mathrm{N}$, supporting previous studies (Brito et al., 2007). Omasal flow of $\mathrm{NH}_{3}-\mathrm{N}$ tended to be greater in cows fed the high-CP compared with the low$\mathrm{CP}$ diet, which was expected, as omasal flow of $\mathrm{NH}_{3}-\mathrm{N}$ is reflective of ruminal $\mathrm{NH}_{3}-\mathrm{N}$ concentration (Brito and Broderick, 2007); however, feeding W-DDGS or B-DDGS did not influence the omasal flow of $\mathrm{NH}_{3}-\mathrm{N}$.

A major objective of the current study was also to determine how interactions between dietary $\mathrm{CP}$ content and source of supplemental protein alter urea-N recycling in dairy cows; however, no interactions were detected for the major variables quantifying urea-N recycling kinetics. Our results indicate that endogenous urea production (i.e., UER) was higher in cows fed the high-CP diet compared with those fed the low-CP diet. This is reflective of the differences in $\mathrm{N}$ intake, as UER is positively correlated with $\mathrm{N}$ intake (Lapierre and Lobley, 2001). For all treatments, the UER:digestible N intake ratios (digestible $\mathrm{N}$ intake was calculated using $\mathrm{N}$ intake and digestibility data that are presented in Table 5) were 0.90 to 1.07 , which fall within the range of 0.43 to 1.23 (mean of 0.88 ) that was reported previously (Lapierre and Lobley, 2001) for lactating cows at various levels of production and fed a wide variety of diets. That UER was 0.90 to 1.07 of digestible N intake clearly indicates the magnitude of the transit of $\mathrm{N}$ into the urea- $\mathrm{N}$ pool and the perpetual reliance of ruminants on urea-N recycling to the GIT to maintain a positive $\mathrm{N}$ balance. If no mechanism existed to recapture some of the UER and all of it was lost in urine, then ruminants would be in negative $\mathrm{N}$ balance. Indeed, GER:UER ratios (i.e., the proportion of endogenous urea-N that was transferred to the GIT) ranged from 0.772 to 0.805 across dietary treatments and this range is in agreement with previous reports (Marini and Van Amburgh, 2003; Marini et al., 2004). Recycled urea-N buffers the forestomachs from the low ruminal $\mathrm{NH}_{3}-\mathrm{N}$ concentration that usually prevails when dietary $\mathrm{CP}$ content is low, thus providing additional $\mathrm{N}$ that can be used to maintain microbial protein synthesis (Lapierre and Lobley, 2001; Reynolds and Kristensen, 2008).

Although cows fed the high-CP diet tended to have greater GER compared with those fed the low-CP diet, most of the recycled urea- $\mathrm{N}$ was reabsorbed as $\mathrm{NH}_{3}$ $\mathrm{N}$ (i.e., ROC). Consequently, the proportion of GER that was used for anabolic purposes (i.e., UUA) was unaffected by dietary CP content. The anabolic utilization of recycled urea- $\mathrm{N}$ is primarily via microbial incorporation of $\mathrm{NH}_{3}-\mathrm{N}$ arising from urea- $\mathrm{N}$ degradation (Lobley et al., 2000). Our observations indicate that the amount of recycled urea- $\mathrm{N}$ that was recovered as microbial NAN was low, ranging from 60.0 to 68.9 $\mathrm{g} / \mathrm{d}$, or 8.5 to $11.5 \%$, when expressed as a proportion of microbial NAN. In dairy cows consuming 350 to 414 $\mathrm{g}$ of $\mathrm{N} / \mathrm{d}$, estimates obtained using ${ }^{15} \mathrm{~N}$ isotope dilution techniques indicated that 34 to $41 \mathrm{~g}$ (or 12 to $25 \%$, when expressed as a proportion of microbial NAN) of duodenal microbial NAN was derived from recycled urea-N (Ouellet et al. 2002; Lapierre et al., 2008; Ouellet et al., 2010), which is higher than our own estimates. Differences in $\mathrm{N}$ intakes and, as a consequence, ruminal $\mathrm{NH}_{3}-\mathrm{N}$ pool sizes could explain the discrepant results between studies in the proportion of recycled urea- $\mathrm{N}$ that is used for microbial NAN production. The mean $\mathrm{N}$ intake in our study ( $719 \mathrm{~g}$ of $\mathrm{N} / \mathrm{d})$ was approximately $337 \mathrm{~g} / \mathrm{d}$ greater than the mean $\mathrm{N}$ intake $(\sim 382$ $\mathrm{g} / \mathrm{d})$ in the previous studies above. Apart from recycled urea- $\mathrm{N}$, ruminal $\mathrm{NH}_{3}-\mathrm{N}$ for microbial NAN synthesis can also be derived from the degradation of dietary $\mathrm{N}$. As dietary $\mathrm{N}$ intakes increases, therefore, ruminal bacteria become less dependent on recycled urea-N as a source of $\mathrm{NH}_{3}-\mathrm{N}$. Feeding W-DDGS or B-DDGS as the major source of protein did not influence urea-N kinetics. Although a tendency existed for ruminal $\mathrm{NH}_{3}-$ $\mathrm{N}$ concentration to be higher in cows fed W-DDGS compared with those fed B-DDGS, we can surmise that the difference in ruminal $\mathrm{NH}_{3}-\mathrm{N}$ concentration were not 
large enough to elicit the inhibitory effects of $\mathrm{NH}_{3}-\mathrm{N}$ on urea- $\mathrm{N}$ transfer into the rumen.

Our results showed that most of the positive responses in animal performance (i.e., milk yield and composition, and $\mathrm{N}$ efficiency) that we observed were due to changes in dietary $\mathrm{CP}$ content, rather than changes in the major source of dietary CP. Perusal of the literature indicates that reducing dietary $\mathrm{CP}$ content is beneficial in reducing feed costs and $\mathrm{N}$ losses to the environment (Olmos Colmenero and Broderick, 2006b; Hristov et al., 2011); however, responses in milk production to reducing dietary $\mathrm{CP}$ content have been equivocal. In our study, feeding a diet containing $15.2 \%$ CP compared with $17.3 \%$ CP lowered milk yield by 3 $\mathrm{kg} / \mathrm{cow}$ per day. Also, milk protein content and yield decreased by 0.12 percentage units and $140 \mathrm{~g} / \mathrm{d}$, respectively. This decrease in production performance that we observed with the low-CP diet is undesirable for economic reasons, and it could primarily be attributed to a deficiency in MP supply at the small intestine, which was $103 \mathrm{~g} / \mathrm{d}$ lower compared with the high-CP diet. As discussed previously, the lower RDP supply in cows fed the low-CP diet could be responsible for the lower MP supply. Others (Firkins et al., 1986; Allen, 2000) have reported that an insufficient RDP supply can also decrease milk production by reducing fiber digestion, which, in turn, can result in reduced DMI and nutrient supply for milk production. In the present study, DMI was unaffected by dietary RDP content, and apparent ruminal fiber digestion was greater in cows fed the low-CP compared with those fed the high-CP diet; however, total-tract fiber digestion was similar across RDP levels, thus indicating that the lower ruminal fiber digestion with the high-RDP diet was offset by higher postruminal fiber digestion. Apparent total-tract digestibility of DM and $\mathrm{N}$ were actually lower in cows fed the low-RDP compared with those fed the high-RDP diet, suggesting that the lower milk yield in cows fed the low-RDP diet could partly be attributed to a reduction in nutrient supply.

Feed efficiency (i.e., milk yield/DMI) was improved when cows were fed the high-CP diet, a response that can be partly attributed to the higher milk yield, as DMI did not change. As expected, cows fed the high$\mathrm{CP}$ diet excreted more $\mathrm{N}$ compared with cows fed the low-CP diet, with this response due to higher urinary $\mathrm{N}$ excretion (rather than fecal $\mathrm{N}$ excretion), as has been reported by others (Olmos Colmenero and Broderick, 2006b; Lee et al., 2011). However, milk N efficiency (i.e., milk $\mathrm{N} / \mathrm{N}$ intake) did not improve when we fed the low-CP diet because the lower $\mathrm{N}$ intake was matched by a lower milk $\mathrm{N}$ content, as has been reported previously (Haque et al., 2012). Across dietary treatments, total N excretion as a proportion of $\mathrm{N}$ intake ranged from 67.7 to $71.0 \%$, which falls within the range that is typically reported in the literature (Castillo et al., 2001). Other indicators of $\mathrm{N}$ use that we measured were PUN and MUN concentrations. Feeding the low-CP diet resulted in lower PUN and MUN concentrations compared with feeding the high-CP diet, as has been reported in other studies in which dietary $\mathrm{CP}$ content has been manipulated (Olmos Colmenero and Broderick, 2006b; Lee et al., 2011). Low concentrations of PUN and MUN suggest efficient use of dietary CP (Olmos Colmenero and Broderick, 2006b).

Feeding W-DDGS or B-DDGS as the major protein source did not influence production responses. Our results indicate that RDP contents in diets containing W-DDGS and B-DDGS were similar at 11.3 and $10.7 \%$, respectively, and were above the recommended range of 9.5 to $10.5 \%$ for maximum microbial protein synthesis (NRC, 2001). It is not surprising, therefore, that the source of dietary protein did not influence microbial NAN and MP supply and, as a consequence, milk production was unaffected by source of dietary protein.

\section{CONCLUSIONS}

Results from this study indicate that feeding a diet containing $15.2 \%$ CP compared with $17.3 \%$ CP lowered milk production. This response was partly attributed to an insufficient supply of RDP that suppressed microbial NAN synthesis in the rumen, thus resulting in a lower intestinal MP supply. Our results also indicate that feeding up to $10 \%$ of dietary DM as B-DDGS or W-DDGS results in similar levels of omasal MP supply and milk production in dairy cows; thus, W-DDGS and B-DDGS are comparable as sources of protein in dairy cow diets.

\section{ACKNOWLEDGMENTS}

The authors thank Marlene Fehr and staff of the Greenbrae Dairy Research Facility (University of Saskatchewan, Saskatoon, SK, Canada) for animal care and excellent technical assistance. This research was supported by the Government of Saskatchewan's Agriculture Development Fund (ADF).

\section{REFERENCES}

Abdelqader, M. M., and M. Oba. 2012. Lactation performance of dairy cows fed increasing concentrations of wheat dried distillers grains with solubles. J. Dairy Sci. 95:3894-3904.

Agle, M., A. N. Hristov, S. Zaman, C. Schneider, P. M. Ndegwa, and V. K. Vaddella. 2010. Effect of dietary concentrate on rumen function, digestibility, and nitrogen losses in dairy cows. J. Dairy Sci. 93:4211-4222. 
Allen, M. S. 2000. Effects of diet on short-term regulation of feed intake by lactating dairy cattle. J. Dairy Sci. 83:1598-1624.

AOAC (Association of Official Analytical Chemists). 1990. Official Methods of Analysis. 15th ed. AOAC, Arlington, VA.

Archibeque, S. L., J. C. Burns, and G. B. Huntington. 2001. Urea flux in beef steers: Effects of forage species and fertilization. J. Anim. Sci. 79:1937-1943

Balcells, J., J. A. Guada, C. Castrillo, and J. Gasa. 1993. Rumen digestion and urinary excretion of purine derivatives in response to urea supplementation of sodium-treated straw fed to sheep. $\mathrm{Br}$. J. Nutr. 69:721-732.

Boila, R. J., and J. R. Ingalls. 1994a. The ruminal degradation of dry matter, nitrogen and amino acids in wheat-based distillers dried grains in sacco. Anim. Feed Sci. Technol. 48:57-72.

Boila, R. J., and J. R. Ingalls. 1994b. The post-ruminal digestion of dry matter, nitrogen and amino acids in wheat-based distillers dried grains and canola meal. Anim. Feed Sci. Technol. 49:173-188.

Brake, D. W., E. C. Titgemeyer, M. L. Jones, and D. E. Anderson. 2010. Effect of nitrogen supplementation on urea kinetics and microbial use of recycled urea in steers consuming corn-based diets. J. Anim. Sci. 88:2729-2740.

Brito, A. F., and G. A. Broderick. 2007. Effects of different protein supplements on milk production and nutrient utilization in lactating dairy cows. J. Dairy Sci. 90:1816-1827.

Brito, A. F., G. A. Broderick, and S. M. Reynal. 2007. Effects of different protein supplements on omasal nutrient flow and microbial protein synthesis in lactating dairy cows. J. Dairy Sci. 90:18281841

Brito, A. F., G. F. Tremblay, H. Lapierre, A. Bertrand, Y. Castonguay, G. Bélanger, R. Michaund, C. Benchaar, D. R. Ouellet, and R. Berthiaume. 2009. Alfalfa cut at sundown and harvested as baleage increases bacterial protein synthesis in late-lactation dairy cows. J. Dairy Sci. 92:1092-1107.

Broderick, G. A. 2003. Effects of varying dietary protein and energy levels on the production of lactating dairy cows. J. Dairy Sci. 86:1370-1381.

Broderick, G. A., P. Huhtanen, S. Ahvenjärvi, S. M. Reynal, and K. J. Shingfield. 2010. Quantifying ruminal N metabolism using the omasal sampling technique in cattle - A meta-analysis. J. Dairy Sci. 93:3216-3230.

Broderick, G. A., and J. H. Kang. 1980. Automated simultaneous determination of ammonia and total amino acids in ruminal fluid and in vitro media. J. Dairy Sci. 63:64-75.

Broderick, G. A., N. D. Luchini, S. M. Reynal, G. A. Varga, and V. A. Ishler. 2008. Effect on production of replacing dietary starch with sucrose in lactating dairy cows. J. Dairy Sci. 91:4801-4810.

Canadian Council on Animal Care. 1993. Guide to the Care and Use of Experimental Animals. Vol. 1. Canadian Council on Animal Care (CCAC), Ottawa, Ontario, Canada.

Castillo, A. R., E. Kebreab, D. E. Beever, and J. France. 2001. A review of efficiency of nitrogen utilization in lactating dairy cows and its relationship with environmental pollution. J. Anim. Feed Sci. $9: 1-32$

Chibisa, G. E., D. A. Christensen, and T. Mutsvangwa. 2012. Effect of replacing canola meal as the major protein source with wheat distillers grains with solubles on ruminal function, microbial protein synthesis, omasal flow, and milk production in cows. J. Dairy Sci. 95:824-841.

Erwin, E. S., G. J. Marco, and E. M. Emery. 1961. Volatile fatty acids analyses of blood and rumen fluid by gas chromatography. J. Dairy Sci. 44:1768-1771.

Firkins, J. L., L. L. Berger, N. R. Merchen, G. C. Fahey Jr., and D. R. Nelson. 1986. Effects of feed intake and protein degradability on ruminal characteristics and site of digestion in steers. J. Dairy Sci. 69:2111-2123.

France, J., and R. C. Siddons. 1986. Determination of digesta flow by continuous marker infusion. J. Theor. Biol. 121:105-120.

Haque, M. N., H. Rulquin, A. Andrade, P. Faverdin, J. L. Peyraud, and S. Lemosquet. 2012. Milk protein synthesis in response to the provision of an "ideal" amino acid profile as 2 levels of metabolizable protein supply in dairy cows. J. Dairy Sci. 95:5876-5887.
Hristov, A. N., M. Hanigan, A. Cole, R. Todd, T. A. McAllister, P. M. Ndegwa, and A. Rotz. 2011. Review: Ammonia emissions from dairy farms and beef feedlots. Can. J. Anim. Sci. 91:1-35.

Huhtanen, P., P. G. Brotz, and L. D. Satter. 1997. Omasal sampling technique for assessing fermentative digestion in the forestomach of dairy cows. J. Anim. Sci. 75:1380-1392.

Huhtanen, P., and A. N. Hristov. 2009. A meta-analysis of the effects of dietary protein concentration and degradability on milk protein yield and milk $\mathrm{N}$ efficiency in dairy cows. J. Dairy Sci. 92:3222-3232

Lapierre, H., and G. E. Lobley. 2001. Nitrogen recycling in the ruminant: A review. J. Dairy Sci. 84(E. Suppl.):E223-E236.

Lapierre, H., D. R. Ouellet, R. Berthiaume, R. Martineau, G. Holtrop, and G. E. Lobley. 2008. Distribution of ${ }^{15} \mathrm{~N}$ in amino acids during ${ }^{15} \mathrm{~N}$-leucine infusion: Impact on the estimation of endogenous flows in dairy cows. J. Dairy Sci. 91:2702-2714.

Lee, C., A. N. Hristov, K. S. Heyler, T. W. Cassidy, M. Long, B. A. Corl, and S. K. R. Karnati. 2011. Effects of dietary protein concentration and coconut oil supplementation on nitrogen utilization and production in dairy cows. J. Dairy Sci. 94:5544-5557.

Lobley, G. E., D. M. Bremner, and G. Zuur. 2000. Effects of diet quality on urea fates in sheep as assessed by refined, non-invasive $\left[{ }^{15} \mathrm{~N}^{15} \mathrm{~N}\right]$ urea kinetics. Br. J. Nutr. 84:459-468.

Marini, J. C., J. D. Klein, J. M. Sands, and M. E. Van Amburgh. 2004. Effect of nitrogen intake on nitrogen recycling and urea transporter abundance in lambs. J. Anim. Sci. 82:1157-1164.

Marini, J. C., and M. E. Van Amburgh. 2003. Nitrogen metabolism and recycling in Holstein heifers. J. Anim. Sci. 81:545-552.

Marsh, W. H., B. Fingerhut, and E. Kirsch. 1957. Determination of urea nitrogen with the diacetyl method and an automatic dialyzing apparatus. Am. J. Clin. Pathol. 28:681-688.

NRC. 2001. Nutrient Requirements of Dairy Cattle. 7th rev. ed. Natl. Acad. Sci., Washington, DC.

Nuez Ortín. W. G., and P. Yu. 2009. Nutrient variation and availability of wheat DDGS, corn DDGS and blend DDGS from bioethanol plants. J. Sci. Food Agric. 89:1754-1761.

Nuez-Ortín, W. G., and P. Yu. 2010. Estimation of ruminal and intestinal digestion profiles, hourly effective degradation ratio and potential $\mathrm{N}$ to energy synchronization of co-products from bioethanol processing. J. Sci. Food Agric. 90:2058-2067.

Nuez-Ortín, W. G., and P. Yu. 2011. Using the NRC chemical summary and biological approaches to predict energy values of new co-product from bio-ethanol production for dairy cows. Anim. Feed Sci. Technol. 170:165-170.

Olmos Colmenero, J. J., and G. A. Broderick. 2006a. Effect of dietary crude protein concentration on ruminal nitrogen metabolism in lactating dairy cows. J. Dairy Sci. 89:1694-1703.

Olmos Colmenero, J. J., and G. A. Broderick. 2006b. Effect of dietary crude protein concentration on milk production and nitrogen utilization in lactating dairy cows. J. Dairy Sci. 89:1704-1712.

Orth, R. 1992. Sample day and lactation report. DHIA 200 Fact Sheet A-2. Mid-States Dairy Records Processing Center (DRPC), Ames, IA

Ouellet, D. R., R. Berthiaume, G. Holtrop, G. E. Lobley, R. Martineau, and H. Lapierre. 2010. Effect of method of conservation of timothy on endogenous nitrogen flows in lactating dairy cows. J. Dairy Sci. 93:4252-4261.

Ouellet, D. R., M. Demers, G. Zuur, G. E. Lobley, J. R. Seoane, J. V. Nolan, and H. Lapierre. 2002. Effect of dietary fiber on endogenous nitrogen flows in lactating dairy cows. J. Dairy Sci. 85:3013-3025.

Reynal, S. M., and G. A. Broderick. 2005. Effect of dietary level of rumen-degradable protein on production and nitrogen metabolism in lactating dairy cows. J. Dairy Sci. 88:4045-4064.

Reynal, S. M., G. A. Broderick, S. Ahvenjärvi, and P. Huhtanen. 2003. Effect of protein supplements of differing degradability on omasal flow of microbial and undegraded protein. J. Dairy Sci. $86: 1292-1305$

Reynolds, C. K., and N. B. Kristensen. 2008. Nitrogen recycling through the gut and the nitrogen economy of ruminants: An asynchronous symbiosis. J. Anim. Sci. 86(E. Suppl.):E293-E305. 
SAS Institute. 2004. SAS/STAT 9.1 User's Guide. SAS Institute Inc., Cary, NC.

Siddons, R. C., J. Paradine, D. E. Beever, and P. R. Cornell. 1985. Ytterbium acetate as a particulate-phase digesta-flow marker. Br. J. Nutr. 54:509-519.

Van Soest, P. J., J. B. Robertson, and B. A. Lewis. 1991. Methods for dietary fiber, neutral detergent fiber, and nonstarch polysaccharides in relation to animal nutrition. J. Dairy Sci. 74:3583-3597.

Vicente, F., A. Sarraseca, A. de Vega, and J. A. Guada. 2004. Performance of several $\mathrm{Cr}$ and $\mathrm{Yb}$ analytical techniques applied to samples of different biological origin (digesta or faeces). J. Sci. Food Agric. 84:2035-2040.

Wickersham, T. A., E. C. Titgemeyer, and R. C. Cochran. 2009a Methodology for concurrent determination of urea kinetics and the capture of recycled urea nitrogen by ruminal microbes in cattle. Animal 3:372-379.
Wickersham, T. A., E. C. Titgemeyer, R. C. Cochran, and E. E. Wickersham. 2009b. Effect of undegradable intake protein supplementation on urea kinetics and microbial use of recycled urea in steers consuming low-quality forage. Br. J. Nutr. 101:225-232

Yang, W. Z., and K. A. Beauchemin. 2005. Effects of physically effective fiber on digestion and milk production by dairy cows fed diets based on corn silage. J. Dairy Sci. 88:1090-1098.

Zhang, S. Z., G. B. Penner, M. Abdelqader, and M. Oba. 2010a. Effects of feeding alfalfa hay on chewing, rumen $\mathrm{pH}$, and milk fat concentration of dairy cows fed wheat dried distillers grains with solubles as a partial substitute for barley silage. J. Dairy Sci. 93:3243-3252.

Zhang, S. Z., G. B. Penner, W. Z. Yang, and M. Oba. 2010b. Effects of partially replacing barley silage or barley grain with dried distillers grains with soluble on rumen fermentation and milk production of lactating dairy cows. J. Dairy Sci. 93:3231-3242. 